\title{
A Review of Projects and Construction Law Practice in Saudi Arabia
}

\author{
Abdullah Khalid Medallah ${ }^{1}$ \\ ${ }^{1}$ LL.M, MCiArb, PMP, MEng (Construction), BSc (Islamic Law), BEng, Principal of Abdullah Medallah Law \\ Firm, Chairman of Kinaz Capital Group, and hold other directorship positions
}

Correspondence: Abdullah Khalid Medallah. E-mail: abd.medallah@gmail.com

$\begin{aligned} & \text { Received: November 16, } 2014 \\ & \text { Accepted: November 21, } 2014 \quad \text { Online Published: February 25, } 2015 \\ & \text { doi:10.5539/jpl.v8n1p94 }\end{aligned}$ URL: http://dx.doi.org/10.5539/jpl.v8n1p94

\begin{abstract}
Construction law in Saudi Arabia has never seen greater appeal. The key discussion of the paper is a review of the practice for projects and construction law, and how a lawyer can represent and advise clients of the construction industry in Saudi Arabia. The discussion will examine key available legislative sources, authorities, literatures, and media in Saudi Arabia. The research will evaluate the above to explicate the current international understanding of Saudi projects and construction law practice. The framework of the paper is merely a review of key areas of the practice extracting them from syllabus of courses teaching construction law in international universities. In addition to academic research, points of discussion are cited from local newspapers mainly those commented by well-known practitioners. The key advantage the reader will have after reading this paper is to know more how the understudy jurisprudence and law has emerged. The delivered view here is that the legal and regulatory system may have many ambiguous areas and shortcomings for foreign lawyers. But, the issue is not being on the top agenda of supreme authority of the Kingdom. This was inaugurated because it is almost inherently built in the system that parties have greater latitude to choose their own preference of how to configure the documentation and the structure of the project. The aim, at the end, is to assist international lawyers in how to practically represent and advise clients in Saudi Arabia. Also, consequently, enlighten their instincts to the recently increasing disputes and potential failures of projects in the Kingdom.
\end{abstract}

Keywords: construction lawyer, Saudi Arabia, Sharia'a (Islamic) law, dispute resolution, procurement law, construction law, and projects law

\section{Introduction}

Professionals in the construction industry know that it is almost impossible to understand or review every aspect of the law that related to construction. ${ }^{1}$ Hence, civil and construction professionals have tended to take courses in construction contracts and law best suited to address this dilemma. ${ }^{2}$ Nevertheless, with the diverse nature of complexities and the channels of communication in a construction project, together with the need to understand greater aspects of the law, it is very important to have a dedicated lawyer who has the knowledge to advise and represent clients and who understands the construction process. ${ }^{3}$ This interdisciplinary integration better serve the industry and, at some level, reduces the burden of having too many experts at the table. ${ }^{4}$ The practice of such a speciality may not need a dual-qualification in law and construction, a qualified lawyer may take courses equipping him to understand the complex issues of the industry alongside practical experience in actual cases.

Construction projects, in nature, highly depend on personal skills, expertise, and technical ability of the staff placed to deliver such projects. 5 Just as to same level of importance, managing construction projects require understanding of the temporary nature, the results-driven, and the unique flow of phases and knowledge

\footnotetext{
1 JONES, S. R. (1994). How constructive is construction law? Construction Law Journal, 10 28-28; see also STIPANOWICH, T. J. (1998). Reconstructing construction law: Reality and reform in a transactional system, Wis. L. Rev., 463

${ }^{2}$ GERBER, P. (2010). The Teaching of Construction Law and the Practice of Construction Law: Never the Twain Shall Meet?, Legal Education Review, Vol. 20, No. 1, p. 84

${ }^{3}$ GERBER 2010, supra note 2

${ }^{4}$ CAMERON, J. G. (2000). A Practitioner's Guide to Construction Law, Library of Congress, p- $\$ 19.02$

${ }^{5}$ CERAN, T and DORMAN, A. (1995). The Complete Project Manager, Journal of Architectural Engineering, vol 1, No. 2, ASCE.
} 
involved in a construction project. ${ }^{6}$ One of the difficulties in Saudi projects basically revolves around having the role of the construction lawyer not fully understood by clients and industry practitioners. Those projects are sensitive with respect to the nature of their scope, time, and budget. It can be said that matters related to, inter alia, delays, payments, disputes, corruption, and manpower issues in the Kingdom are enough to show the need for lawyers in the industry. ${ }^{7}$ Although, the paper is advancing multiple advisory areas which expected to be carried out by a team of lawyers in a law firm, for the purpose of exploring the hypothesis of the paper, the discussion will presume one construction lawyer is providing such service. Having said that, nevertheless, one of the implied drivers to this paper is examining what makes the practice in Saudi Arabia unique and probably difficult to find references for. ${ }^{8}$

The aim of this paper, however, is to assist local and international construction lawyers who practice or represent clients in projects governed by the jurisdiction of Saudi Arabia with recent developments in the law related to the industry. In the absence of the application of stare decisis ${ }^{9}$ and the exceptionality of the socio-legal limitations, most of the in-kingdom legal practice, ranging from choosing a standard form of contract to choosing a method of delay analysis, is normally codified from other jurisdictions. ${ }^{10}$ While, there are no reference for reporting mechanism that is approved by the Ministry of Justice (MoJ) to attempt to assist the practice of construction law in specific, ${ }^{11}$ the judiciary had an attempt to record all judicial decisions 'Modona Al Ahkam'12 and placing them in an open source system. This attempt has somehow never received serious implementation. ${ }^{13}$

In order to assist the international reader, the paper will draw an analogy citing in the discussion multi-jurisdictional views and may cite judgements from other jurisdictions, but such judgments cannot be said to have the same enforcement effect in Saudi Arabia.

Another constraint of the discussion, as it is fairly difficult to examine all the areas of construction law practice together in one paper is exhausting the content of the practice. For that the framework of the review will be based on the best practice of teaching construction law in international universities. ${ }^{14}$ Thus, by looking at how academics and practitioners ${ }^{15}$ are configuring the assembly of the construction law body-of-knowledge, this framework will then be assembled as the following:

1- General View of the Market: examining how the practice has evolved internationally and in Saudi Arabia.

2- Drafting construction legal documents: taking into examination sources of law in Saudi Arabia, review of jurisprudential principles, and the distinction of contracts governed by the law of the kingdom.

\footnotetext{
${ }^{6}$ CLELAND, D. and IRELAND, L. (2002). Project Management: Strategic Design and Implementation, McGraw-Hill, p-39-43; see also Project Management Institute Global Standard. (2009). A Guide to the Project Management Body of Knowledge, $4^{\text {th }}$ ed. ANSI, p-1-14.

${ }^{7}$ AL-KHARASHI, A., and SKITMORE, M. (2009). Causes of delays in Saudi Arabian public sector construction projects. Construction Management and Economics Journal, 27(1). pp. 3-23

${ }^{8}$ HUSEIN, A. T. (2013). Construction and Projects in Saudi Arabia: overview Practical Law, Multi-jurisdictional Guide 2013-14, practicallaw.com/2-534-0319.

9 JACKSON, S. A. (2003-2004). Shari'ah, Democracy, and the Modern Nation-State: Some Reflections on Islam, Popular Rule, and Pluralism, Fordham Int'l L.J. , 27.

${ }^{10}$ OTTO, J. M. (2010). Sharia Incorporated: A Comparative Overview of the Legal Systems of Twelve Muslim Countries in Past and Present, London: Praeger, p 161-162.

${ }^{11}$ SHABRAWI, A. A. (2012). Ministry of Justice Publishes Seven Modonas, Okaz Newpaper Madinah, Saudi Arabia Okaz Publishing, 22 Feb, 2012

${ }^{12}$ Ministry of Justice (2012). Modona Al Ahkam, MOJ, $1^{\text {st }}, 2^{\text {nd }}$, and $3^{\text {rd }}$ versions

http://www.moj.gov.sa/ar-sa/ministry/versions/Pages/Modona.aspx

${ }^{13}$ SHABRAWI 2012, supra note 11

${ }^{14}$ GEBER 2010, supra note 2 included: introduction of construction law and the construction industry, traditional construction contracts, alternative construction contracts, time issues, payment issues, quality of work issues, variations and changes, construction site visit, latent conditions, insurance, security for performance, dispute avoidance process, and dispute resolution

${ }^{15}$ RAMSEY, V. \& TELFORD, T. (2007). Construction Law Handbook, London, Thomas Telford Publisher; Telford and Ramsey text book for students studying construction law as four parts: Part - 1: Legal issues arsing during construction: 1) the planning system, 2) project finance, 3) Public- Private Partnerships, 4) Tender Process, 5) Construction contracts, and 6) Construction insurance. Part - 2: Organising and Engineer's Practice: 1) Ways of operating, 2) working with others, 3) working internationally, 4) the engineer's appointment, 5) collateral warranties, 6) professional indemnity insurance, 7) employment law, and 8) Information technology in construction. Part - 3: General Law: 1) the law of contract, 2) construction health and safety, 3) insolvency in construction, 4) law of tort, and 5) environmental issues. Part - 4: Construction Disputes: 1) Administration of claims, 2) Litigation, and 3) Arbitration
} 
3- Projects Practice Areas which will include Procurement and delivery routes: explaining the widely used routes and what is available in Saudi Arabia; Public Procurement: reviewing the Public Procurement Law in the country; Project Financing: exploring Islamic Finance alternatives in Construction; Insurance and Risks Issues: exploring the Takaful insurance scheme and generally available policies.

4- Construction Practice Areas: Costing and Loss \& Expense Issues: exploring issues and admissibility of methods of ascertainment; Time \& Schedule Issues: exploring time issues and matters linked to delay penalties and damages; Quality and Defect Issues: exploring quality issues and warranty requirements in liability periods; Duties and responsibilities Issues: exploring key duties of those involved in the construction industry.

5- Dispute Resolution: a general view of the practice in Saudi Arabia.

6- Corruption and Project Forensics: exploring the general views in Saudi.

\section{General View of the Market}

It is a worldwide stereotype that lawyers fee are relatively high. ${ }^{16}$ Clients normally try to avoid paying such a fee unless it involves a complex issue or a dispute. Nonetheless, in Saudi Arabia the dependence on seeking a legal advice is still a limited routine of the local business world. ${ }^{17}$ Conversely, where the position has been further examined, for example, in the late 1990s in the United States, a survey showed practising construction lawyers were confronted with a lack of cost control, a lack of understanding of client needs, and a lack of innovation. ${ }^{18}$ These made the industry practitioners suffer a lack of trust in the practise itself. In fact, only $17 \%$ among them had lawyers drafting their contracts. ${ }^{19}$ Hence, the same survey declared a subcontractor's view in the United States, which saw a trustful dependence on those who prosper under the US lien law. ${ }^{20}$ The situation is still not examined in Kingdom, as it is hardly seen to have lawyers involved in the development of construction contracts or its associated advisory documentation.

In another view, there are those who believe, presumably here the discussion is about non-contentious lawyers, that the lawyer's role must focus on building consensus and effective communication. ${ }^{21}$ This lies in the fact that he may recognize legal opportunities and threats prior to any contractual commitments. His ability to understand the consequences of actions will be better deployed if it can be used in building and forming such consensus between project members. In view of his capacity, there are practitioners who believed that his position might also satisfy the requirement of deploying an impartial third-party for the whole project to provide better independent advisory services. ${ }^{22}$ Presumably, this was under the belief that having an external view adds value to the synergy of the team notwithstanding, having him a lawyer, advantageously promote disclosure enhancement or confidentiality and may recognise the foundation of intellectual property rights and duties of the involved practitioners or producers. From another view, on the contrary, others raised an alert in connection with how impartial his advice is regarded. ${ }^{23}$ The answer mainly lies in the business environment and the jurisdiction the lawyer is practicing in. The Saudi business environment may still have long to expect such an independent lawyer involved.

In Saudi Arabia, legislatively, construction law is an area that is potentially driving toward acquiring legal knowledge from other jurisdictions and tailoring it to fit the Saudi local laws. ${ }^{24}$ What makes the challenge in

\footnotetext{
${ }^{16}$ SIOMN, R. D. (1989). Fee Sharing between Lawyers and Public Interest Groups, Jr. The Yale Law Journal, Vol. 98, No. 6 (Apr., 1989), pp. 1069-1133

17 SHAMMA. S, (1965). Law and Lawyers in Saudi Arabia, International \& Comparative Law Quarterly, vol-14(3), p-1034; see also KARL, D. J.(1992). Islamic Law in Saudi Arabia: What Foreign Attorney's Should Know, 25 Geo. Wash. J. Int'l L. \& Econ. 131 (1991-1992)

${ }^{18}$ HOLLOWAY, J. (1996). Construction disputes and legal services - could lawyers do better?, Cons. Law 1996, 7(2), 47-49; see also Comm. Law. (2001). Construction lawyers: the in-house verdict, Commercial Lawyer Journal, 43 Supp, (Special report construction), v-9.

19 TOCCO, J. (1992). Analysis of a Survey: How Contractors Use Lawyers in Construction Disputes, 12 Constr. Law. NO.3

${ }^{20}$ HUNT, G. and GIBBS, K. (2000). California Construction Law, $16^{\text {th }}$ ed. Aspen Pub., 9.03[D].

${ }^{21}$ JONES 1994, supra note 1; see also NOBLE, C. (1998). Friend of the project - a new paradigm for construction law services in a "partnered" construction industry, I.C.L. Rev. 1998, 15(1), 78-84.

${ }^{22}$ GEISINGER, E. (2009). Dispute avoidance in international construction projects: the use of outside counsel as contract manager, Const. L.J. 2009, 25(1), 11-23

${ }^{23}$ REDFERN, A. (2004). Law and Practice of International Commercial Arbitration, $4^{\text {th }}$ ed, Swt \& Max, p-207

${ }^{24}$ TIEDER, J.B. (1998). The globalization of construction - evolving international standards of construction law, I.C.L. Rev. 1998, 15(4), 550-606; see also DALBY, J. (1998). EU law for the construction industry, Cons. Law 1998, 9(6), 212; see also MARRIOTT, A. L. (1998). Does Hong Kong need a new construction law?, Const. L.J. 1998, 14(2), 94-100; see also MATHURIN, C. (1988). Construction law in the
} 
Saudi Arabia is the uncodified law; as it is hard for foreign lawyers to encompass how the overall legal regulatory system works in the country. ${ }^{25}$ The conflict between Sharia'a law and contracts governed from common and civil jurisdictions may have enlarged the void further. It has been clear that enforcement of Sharia'a laws has created a fear of some international companies and professionals. ${ }^{26}$ But, other areas of common knowledge have contributed to assist the configuration of practise, especially where the practice of project management, procurement procedures, engineering designs, construction technologies, and commercial export/import agreements are almost standardized.

\section{Drafting Projects and Construction Legal Documents}

Neither the lawyer's personal skills of being approachable, precise, and accurate, nor his acquired skills in negotiation, presentation, and problem solving are enough to satisfy the demands imposed upon him. Likewise, his technical and legal strength is vital, however, because he is representing the law to his client, he has to deliver more than consultations and advisory services. His persistence in avoiding issues or disputes for his client and proactively looking for areas of potential conflict is, among previous criteria, fundamental to better serve them. Moreover, communicating those issues to other project members' will evidently not only be cost-significant, but also build a cooperative paradigm among other project members. Having said that, alongside with his communication and negotiations, the prime deliverable for him is construction and projects related documentations.

The first point of acquaintance of the lawyer with the construction industry pertains to the standard forms of contract. ${ }^{27}$ As the Saudi construction industry lacks any standard forms, he will have to develop bespoke forms which sets the ground for alternative risk apportionments, administrative practices, and legal or contractual remedies. ${ }^{28}$ A great portion of a construction lawyer's effort will be dedicated to assist in administration of the legal issues, ${ }^{29}$ since he, aligned with the duty of the project manager, will have a role in integrating scope, time, finance, risks in project documents and contracts. He must understand risk planning as to iterate or be able to understand potential risks to assist in refining project documents to keep them in accordance with the law. ${ }^{30} \mathrm{He}$ must also establish an index mechanism to monitor and control the processes of execution of documents and negotiations from his own legal perspective. ${ }^{31}$ For example, in time-related issues, with regard to the ownership of the float in the schedule, his legal understanding of the ownership of the float will enrich a decision when progress begins to spin out of control. Therefore, his endeavours will be best applied to form a suite of documents, where together, may have an annexure to explain the position of float in the project; some can call it Schedule Dictionary. Some of other documents normally seen in a construction project are, inter alia, the project charter, bespoke agreements and sub-agreements, joint ventures, consortiums, scope statement, finance agreement, insurance policies, and other related documents. ${ }^{32}$

All Sharia'a-complaint construction contracts are in origin 'Istisna' $a$ ' contracts. Today, when construction practitioners refer to a construction contract they call it Moqawlah- they do not call it Istisna' $a$ contract. Even a contractor will be called Moqawel. Those Moqawlah contracts have the option of novation in case a client wanted to shift for example design liability. ${ }^{33}$

European Community, P.L.T. 1988, 3(Apr), 4-6; see also KOHL, B. (2009). European construction law and the Draft Common Frame of Reference: selected topics, E.R.P.L. 2009, 17(4), 675-702.

${ }^{25}$ SHAMMA 1965, supra note 17 ; see also KARL 1992, supra note 17

${ }^{26}$ SHAMMA 1965, supra note 17; see also KARL 1992, supra note 17

${ }^{27}$ SWEET, J. (1991). Standard construction contracts: some advice to construction lawyers, Const. L.J., 7(1), 8-23.

28 JONES 1994, supra note 1

${ }^{29}$ SMALL, D. (1990). In-house lawyers: from lawyer to manager, L.S.G. 1990, 87(14), 33-34, 40; see also WHITTAKER, A.M. (2003). Lawyers as risk managers, B.J.I.B. \& F.L. 2003, 18(1), 5-7.

${ }^{30}$ WHITTAKER 2003, supra note 26

${ }^{31}$ PMI 2009, supra note 11

32 ELKARKOURI, D. (1992). Pre-contractual liability in Islamic construction contracts, I.B.L.J. 1992, 7, 835-848.

${ }_{33}$ Citing commentary on the UK case Blyth \& Blyth Ltd $v$ Carillion Construction Ltd [2001] G.W.D. 13-473; see also LOVE, P. E., SKITMORE, M., \& EARL, G. (1998). Selecting a suitable procurement method for a building project, Construction Management \& Economics, 16(2), 221-233.; see also AKINTOYE, A. (1994). Design and build: a survey of construction contractors' views, Construction Management and Economics, 12(2), 155-163; see also CHAN, A. P. (1994). Evaluation of novation contract, In Proceedings of the National Construction and Management Conference, Sydney, Australia, February 17-18 1994 (p. 129). Institution of Engineers, Australia; see also AL-HAMMAD, A., \& ASSAF, S. (1992). Design-Construction interface problems in Saudi Arabia: Survey showed that working drawing details, unfamiliarity with local conditions and buildability ranked as highest interface problems, Building research and information, 20(1), $60-63$ 
As any other business agreements, the principles of contract law constitute the core basics Moqawlah agreements. ${ }^{34}$ The broad knowledge of these principles must be extended to include the law of remedies and resolution of disputes. ${ }^{35}$ Meanwhile, in another regard, it is of great magnitude, even though tort does not apply in Saudi Arabia, that a construction lawyer understands the equivalent application of negligence ${ }^{36}$ in Moqawlah agreements. Such an application will govern the duty of care assumed against the employer, other professionals, and the public. ${ }^{37}$ The analogy is mostly seen in Qisas and Hadd Theories. ${ }^{38}$ In addition, in the formation of Moqawlah contract, together with public legislation and international treaties, the law of corporate law, legal capacities must be understood, which has a distinct application in Saudi Arabia. ${ }^{39}$ Age, for example, may not be the foundation to decide maturity of a person in Saudi Arabia. All of these areas of local law must be understood, structured, and then documents to be drafted and comprehended to all entities involved in a construction project.

Besides, the necessity for lawyers to understand areas of law, they have to learn when the choice-of-law is the Law of the Kingdom of Saudi Arabia, that Sharia'a law will govern such documents. ${ }^{40}$ The key fundamentals of Sharia'a knowledge base that a lawyer must possess before drafting are summarised and discussed below.

\subsection{Sources of the Law}

If the choice-of-law is the law of the Kingdom of Saudi Arabia, it is crucial that the lawyer visit the sources of the law in Kingdom. Sharia'a is the source of the principal jurisprudence in the Saudi legal environment. ${ }^{41}$ The four main sources of enactment are Quran, Sunnah, Ijma'a, and Qyas. The Quran is the holy book, the verses of which guide Muslims. The Sunnah is the prophecy of Mohammed and covers his sayings, actions, and attitudes. The Hukums are comprised of speeches and approvals; ${ }^{42}$ The Ijima'a is the scholars agreement on certain Hukum ${ }^{43}$ The Qyas - measurement -, is the personal understanding of scholar(s) pertaining to a certain Hukum. ${ }^{44}$ The law is derived from the interpretation of these four sources. Interestingly, the latitude of interpretation $^{45}$ mainly derived from Ijima' $a$ and Qyas heavily lies on those last two pillars of Sharia'a law. This has motivated scholars, Westerners, and legal professionals toward greater analysis of how the law in Saudi Arabia is enacted and understood. In the event of litigation, one of the duties of the construction lawyer is to realize the potential risks to the project arising from the different interpretations that a judge may apply to Sharia law. Even if the contracts are sufficiently standardised to best suit the common 'mathahab"46 in Saudi Arabia, which is the Hanbli school of thought, the construction lawyer must nevertheless understand Asool Al-fegh, ${ }^{47}$ Goaed Al-fegh, ${ }^{48}$ and $\mathrm{Al}_{\text {-fegh }}{ }^{49}$ itself to analyse the reasoning behind a verdict and to avoid potential areas of ambiguity.

\footnotetext{
${ }^{34}$ ARBOUNA, M.B. (2007). The Combination of Contracts in Shariah: A Possible Mechanism for Product Development in Islamic Banking and Finance, Thunderbird International Business Review, Vol 49, Iss. 3.

${ }^{35}$ MAHTANI, N. (1994). Issues concerning performance guarantees and related remedies in construction contracts, I.C.L. Rev. 1994, 11(3), 363-365; see also PEMBLE, S. and WILSON, S. (2010). Seeking Remedies, Estates Gazette, 2010, 1027, 79.

${ }^{36}$ WILMOT-SMITH, R. (2007). Construction Contracts: Law and Practice, Oxford University Press, p-115; see also MURDOCH, J. (1990). Construction law - where are we now?, Estates Gazette, 1990, 9018, 28-29,32; see also NIZAR, H. (1994). Qatar: The Duality of the Legal System, Middle Eastern Studies. Vol. 30, No.1. pp.79-90

${ }^{37}$ HOMSY, P., C. (1982). Legal Aspects of Doing Business in Saudi Arabia, 16 Int'1 L. 51; see also PARADIS, M. (2007). Just Reasonable: Can Linguistic Analysis Help Us Know What It Is to Be Reasonable, 47 Jurimetrics 169.

38 WASTI, T. (2009). An Application of Islamic Criminal Law in Pakistan, Brill, V.2, p-99.

39 RAMDAN, H. M. (2006). Understanding Islamic Law: From Classical to Contemporary, AltaMira Press, p-131; see also RICE, G. (2004). Doing business in Saudi Arabia, Thunderbird International Business Review, 46(1), 59-84; see also MELLAHI, K. (2007). The effect of regulations on HRM: private sector firms in Saudi Arabia, The International Journal of Human Resource Management, 18(1), 85-99.

40 Royal Decree No. 64, 14/7/1395 H.

${ }^{41}$ Royal Decree No. 64, 14/7/1395 H.

${ }^{42}$ HALLAQ, W. (2009). An Introduction to Islamic Law, Cambridge University Press: Cambridge University, p-16-17

${ }^{43}$ HALLAQ 2009, supra note 42 p-16

${ }^{44}$ BADRAN, B. (2002). Nzhaht alkhatr ala'atr shrh ktab roudhah alnathr wjnah almnathra, $1^{\text {st }}$ ed, Dar Al Koutb Al Elmiah; Hallaq 2009, supra note 42 p-16; see also ALSARKHASI, A.(490H) Asool Al Sarkhasi, Ehyaee Al Maraef AlNomanyah, Hyderabad, India; see also HANNAN, S. A. (2004). USUL AL FIQH, Muslims Internet Directory; see also MAKDISI, G. (1984). The Juridical Theology of Shâfi' Origins and Significance of Ușull al-Fiqh, Studia Islamica, 5-47; see also RAMDAN, T. (2008) Radical reform: Islamic ethics and liberation, Oxford University Press, USA; HALLAQ, W. B. (1992) Usül al-Fiqh: Beyond Tradition, Journal of Islamic Studies, 3(2), 172-202

${ }^{45}$ HALLAQ 2009, supra note 42 p-17

${ }^{46}$ BADRAN 2002, supra note 44; HALLAQ 2009, supra note 42 p-17

47 BADRAN 2002, supra note 44; HALLAQ 2009, supra note 42 p-17

${ }^{48}$ BADRAN 2002, supra note 44; HALLAQ 2009, supra note 42 p-17

49 BADRAN 2002, supra note 44; HALLAQ 2009, supra note 42 p-17
} 


\section{2 'Al-fegh' - Jurisprudence in Sharia'a}

In the eighth century, Islamic Jurisprudence became a highly technical area of knowledge, and scholars have since maintained a recognized position to date. ${ }^{50}$ The four main legal schools were: 1) Hanafi school from Iraq (d. 767); 2) Malki school in Madinah (d. 795); 3) Shafi' $i$ school (d. 820), and 4) Hanbali school (d. 855). ${ }^{51}$ The body of knowledge of Islamic jurisprudence has two methodologies. At one end, the Fatwa is the method for finding legal answers for concurrent matters. At the other end, scholars have drawn fictitious problems and impelled legal hypotheses to potential Hukums. ${ }^{52}$ Compiling both ends, the body-of-knowledge contributes to assigning of a certain 'Daleel,' which is extracted as a verse from Quran or Sunnah to the solution of the problem. This eventually becomes the jurisprudence, which is the body of Hukums.

\section{3 'Asool Al-fegh' - Principles of Jurisprudence in Sharia'a}

Asool Al-fegh may be the most difficult area of Sharia'a. Its essence is the ability to set a guideline for lawmakers in how to measure and analyse a certain problem or case. With reference to Islamic jurisprudence, Asool Al-fegh is the body of knowledge behind recognizing what defines a 'Daleel' and how a 'Daleel' will be assigned to a single Hukum. ${ }^{53}$ Put succinctly, if Al-fegh is the body-of-knowledge, Asool al-fegh is the structure underlying that knowledge.

\section{4 'Goaed Al-fegh'- Rules of Jurisprudence in Sharia'a}

After the ages of the first four scholars, ${ }^{54}$ Islamic scholars tried to qualitatively ascertain the rules or boundaries of the technical process to enact a certain Hukum and the guides for the structure underlying the body-of-knowledge. This is when the rules of jurisprudence were established. The rules fall into three categories: 1) Prime Rules, 2) Major Rules, and 3) Partial Rules. ${ }^{55}$ The five prime rules are:

1) 'Alamoor be magasedha' - 'matters linked to their intentions' as straightforward as the first prime rules indicates. Hukums are assessed by intentions more than words. From this rule, scholars extracted other rules, such as: 'In contracts, the concern is intentions and meanings not words and statements. ${ }^{56}$

2) 'Alyageen la yzool be Alshak' - 'certainty does not fade by doubts'. The second rule pertains to the duty to ascertain facts. For example, from this rule, a judge will place the duty on the claimant to prove by prima facie evidence the direct cause of a loss suffered.

3) 'Almashqah tajleb Altayseer' - 'difficulty brings easiness' in Sharia'a. Duties must be fair and reasonable, unlike forbidden acts i.e. adultery, which should account to greater strictness in the law. From this rule was extracted the general Hukum that the 'origin is allowance.' In construction, the engineer bears the duty of correct engineering. It is assumed that the contractor would have greater difficulty in ensuring such correctness.

4) 'La darrar wa la derrar' - 'no harm or harmful action' although this is a general rule that applies to common sense and fair judgments, from this rule, for example, has been extracted the right of "Shoufa' $a$ " in partnerships, where a partner has the right to enforce a sale of shares or to object to them. ${ }^{57}$

5) 'Ala'adah mohakamah' - 'the norm prevails' where it applies to application of common practice or common norms. In construction, the distinct line drawn between conceptual drawings and detailed engineering drawings may be determined by the common practice of engineering in a certain jurisdiction.

Other sub rules provide guidance and are as important as a doctrine in common and civil laws. The integration between the three areas of $f e g h$ becomes the law in Sharia'a. Extracting Hukums from Daleels is in it essence an exercise of deductive reasoning. At the same time, it is inductive in favour of extracting Daleel from Quran and

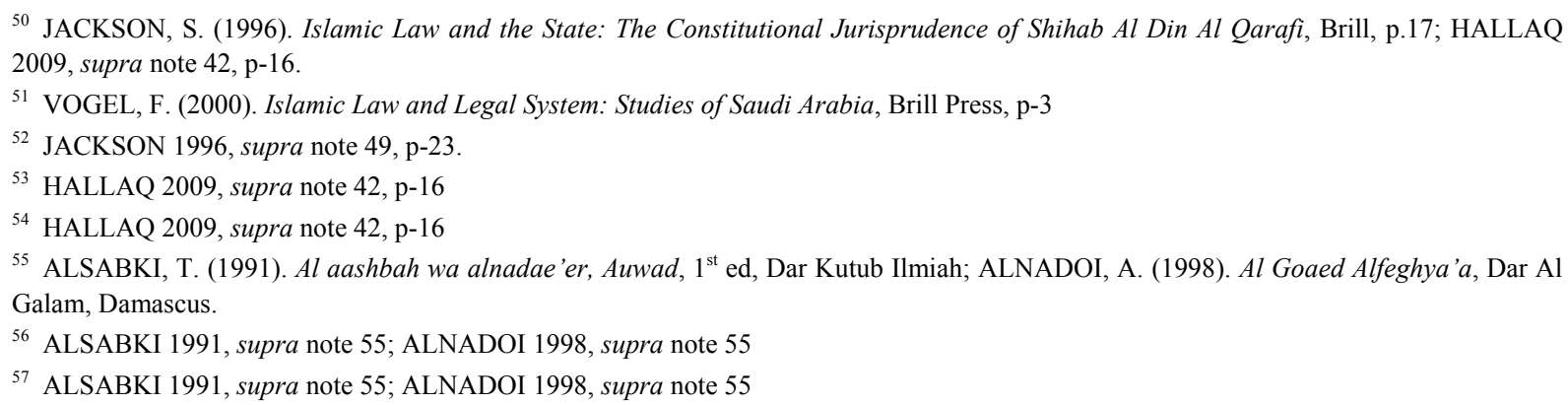


Sunnah. For example, the effect of making a false statement in Sharia'a was clear in the Daleels from Quran and Sunnah:

1. Allah said in Quran: "and whoever honors the sacred ordinances of Allah - it is best for him in the sight of his Lord. And permitted to you are the grazing livestock, except what is recited to you. So avoid the uncleanliness of idols and avoid false statement' Al Hajj 22:30.

2. The Prophet ( ) said, "The biggest of Al-Ka'ba'ir (the great sins) are ... Number 4 and to make a false statement," or said, "to give a false witness." ${ }^{58}$

In 1 and 2 above, we have cited the Daleels that underpin false statements in Islam. As this is a jurisprudential examination, scholars will visit the two Daleels above and with other criteria and body of knowledge, can extract the effect which is translated to be the Hukum. In courts, a judge may, depending on the Hukum, sentence a defendant who makes a false statement to imprisonment as he sees suitable. ${ }^{59}$

\subsection{What Makes a Construction Contract in Sharia'a Different from Other Jurisprudences?}

The general ideology is that there are standard forms of practice that are used internationally and still can be used in Saudi Arabia. Provided that this statement is true, the reasoning behind it is that most such conditions pertain to the general practice in engineering and construction; the norm prevails. ${ }^{60}$ In Sharia'a, there are prime conditions for a contract to take place 'shroot al bai'ee'a' - sale conditions - which are, inter alia: a) a formation of a satisfactory agreement; b) each party must have the right to form a contract; c) the contract purpose must be lawful; d) the ownership/agency of parties; e) the capacity of the parties; f) knowledge of the price; and g) consideration. ${ }^{61}$ These conditions amount to the first level of the rules, and their absence in general may render a contract void, or simply it did not come to existence.

The second level is comprised of the contract's conditions, which are either lawful or unlawful. To distinguish between a lawful condition and an unlawful condition, it is crucial to understand what will constitute a sound contract and what will render it unenforceable or voidable. ${ }^{62}$ The general contract conditions pertaining to: ${ }^{63}$ a) a condition in the nature of the contract; b) a condition pertaining to a benefit- "Manfa' $a$ " of the contract; and c) a condition of a benefit in the consideration. On the other hand, unlawful contracts pertain to conditions within the contract itself, of which there are three types.

In explanation of the first level, is when, for example, two contracts are combined into one. Such a contract usually restricts too many options in the project financing structuring. For example, an Istisna'a contract to finance construction and an Ijarah contract to finance facility operation are bound by strict rules to avoid such unlawfulness i.e. being a one finance agreement. Although solutions to this matter have been maintained, there is a high level of restriction which may render a contract voidable. The general rule is that the condition is lawful only if it does not lead to 'Muhrram' -forbidden issue-. Citing a practice in construction, for example, Design-Build agreements (D\&B) are lawful; although they are two contracts combined into one, provided there has been a clear scope and identification to a level not to say the goods of the contract are uncertain. The lawfulness is acquired as it does not lead to Muharram, however, in Istisna'a-Ijarah agreement it may lead to Riba stipulation.

The second level pertains to rendering a contract voidable. It will generally be comprised, as Hanfi school named them, of 'Facid' clauses, such as, for example, enforcing a percentage of loss in a construction agreement. A very good example is the Target Price contract. If the percentage is imposed on only one party, it may render the clause voidable, and the law will then test the severability of such a clause. The general rule to make such a clause lawful is when both parties share the pain and share the gain.

The third level of contractual conditions that will render a contract voidable pertains to prevent the execution of the contract works. For example, if an employer enforces a clause as a disclaimer to site underground condition. The contractor on the other end has a single freedom-of-choice option and will be held accountable to site conditions without the option to examine the site condition himself. If a void discovered underground, the

\footnotetext{
${ }^{58}$ Sahih al-Bukhari 6871, Book 87, Hadith 10, Vol. 9, Book 83, Hadith 10

59 ALGAHTANI (2001). The Methodology of Extracting Hukums of Fegh in New Matters: Applied and Jurisprudential Study, Om AL Qurra School of Islamic Studies

${ }^{60}$ See 3.4 above.

${ }^{61}$ BADRAN 2002, supra note 44

${ }^{62}$ BADRAN 2002, supra note 44; WILMOT-SMITH 2007, supra note 36

${ }^{63}$ BADRAN 2002, supra note 44
} 
contractor will not be responsible to rectify as it has to be named before the contract can take place and after the buyer's examination. The result the employer's disclaimer is a 'facid' clause, which will render a contract voidable in whole or in part.

The lawyer practicing in Saudi Arabia will mainly have to have bespoke forms of contract to comply with local laws. Instead of having to have a new agreement from scratch, although not of preference, a lawyer may use any standard form ${ }^{64}$ and redraft areas of conflict jurisprudential issues or local laws. Ironically, though, there have been attempts to put together a standard form FIDIC-tailored form ${ }^{65}$ together with pressure from the local media to implement it. ${ }^{66}$ Again, serious implementation did not take effect.

\section{Projects and Procurement Practice Areas}

\subsection{Procurement and Delivery Routes}

Procurement law is one of the most specialized areas commonly seen in construction law, because it governs the framework of the tendering process together with the mechanism of risk apportionment that can hinder the choice of the project delivery route. Procurement law will cover delivery methods, type of bidding, types of contracts, and their legal effects. For example, in the UK, the customary type of delivery route is to require the D\&B contractor to deliver a project fit for its purpose. In contrast, the normal design-bid-build delivery generally imposes liability on the contractor based upon a reasonable skill and care test. ${ }^{67}$ The latter route will require customized types of contracts compatible with such delivery method. ${ }^{68}$ Again, in essence, the same principle of law maybe applied to Saudi jurisdiction. ${ }^{69}$

When choosing a procurement route, the art lies in the ability to draw on the two knowledge areas, law and project management. As most of the effort of planning will be interpreted in the procurement route, the chosen route is a very good measure of the success of a construction lawyer. The most capable lawyer will draft a bulletproof contract that shifts the risk to the person best able to bear it. Aligning that with effective communication during the cycle of the project to avoid potential disputes, will significantly impact on the pillars of the project: scope, time, and cost. ${ }^{70}$ In Saudi Arabia, Fixed-Price agreements are most common. However, it is normal to see other types of contracts, cost-reimbursable, for example, used in the construction of the two holy-mosques or those used by such semi-private organization as Saudi Aramco, the Saudi Mining Company, and the Saudi Electricity Company. The lawyer before choosing the procurement route has to look at the internal capability of the project and the parties/potential parties involved.

\subsection{Public Procurement}

Public procurement is virtually a distinct area of the law, in which there are usually unique provisions of an anti-discriminatory nature to allow greater transparency to the process of awarding contracts. For example, in 2010 , government spending was at its peak, it continued to rise, even though the public media in Saudi dispread views and recently claimed that the public procurement regulations were central to the troubled and severely amounted to failed projects in Kingdom. ${ }^{71}$ Notwithstanding, the fact those governmental contracts are normally poorly written in Arabic language. The main reasons were believed to be the total-risk allocation and low-price mechanism. ${ }^{72}$ Although, there are competent legal teams working in the Ministry of Finance (MoF), and other public ministries, the lawyer has to sensibly consider that the legal knowledge invested in project documents may not be to the level of what is expected to see with semi-private owners' documents as Saudi Aramco. It is still a grey area of law that to what extent the $\mathrm{MoF}$ is delegating greater latitude to public ministries to have their

\footnotetext{
${ }^{64}$ Typically may include: FIDIC, JCT, AIA, NEC, ICE ..etc.

${ }^{65}$ ALKENANI, J (2014). Application of FIDIC terminates the effect of the lowest bidder and subcontracting, Al Riyadh Newspaper, 16712

${ }^{66}$ ALKHURAIF, A. (2013). The assurance of the possibility of apply FIDIC, A1 Riyadh Newspaper, 16568

${ }^{67}$ See the well-known UK case Independent Broadcasting Authority v. EMI Electronics Ltd and BICC Construction Ltd [1980] 14 B.L.R. 1 (HL); see also WRIGHT, J. (2009). Professional Indemnity \& Fitness for Purpose, Cons. Law, 23.

${ }^{68}$ BOWER, D. (2003). Construction Management Series: Management of Procurement, $1^{\text {st }}$ Ed p. 55; see also BROOM, J. (2002). Procurement Routes for Partnering: a Practical Guide, $1^{\text {st }}$ Ed, p. 51; MITCHELL, B. and TREBES, B. (2005). Managing Reality: Procuring an Engineering and Construction Contract, Book-2, Thomas Teleford Publications; see also GOULD, G. (2008). NEC3: Construction contract of the future?, Construction Law Journal.

${ }^{69}$ Read section 3.5 above

${ }^{70}$ DANURI, M.S., HUSSAIN, S.M.N.A., MUSTAFFA, N.E., and JAFFAR, M.S. (2010). Growth of dispute avoidance procedure in the construction industry: a revisit and new perspectives, Const. L.J. 2010, 26(5), 349-363; see also GEISINGER 2009, supra note 22.

71 ABA ALKHAIL, Y. (2013). In Public Procurement: Lowest Bidder Is not the primary factor, Al Riyadh Newspaper, 834385

${ }_{72}$ Royal Decree 58/M, 9/4/1427 H; see also WAS (2013). The Ministry of Finance Explains the Public Procurement Law, 834049; see also ABA ALKHAIL 2013, supra note 70
} 
own bespoke regulations. The MoF has clearly announced in 2013, that public procurement law does not abide public ministries to choose the lowest bidder solely. ${ }^{73}$ It is believed that the criteria to choose a successful bidder are: 1) Qualified permission to perform the work of the project, 2) Economic balance -where the bid does not fall $35 \%$ or lower from the owner estimate-, 3) Overloading, and 4) Consistency of bid documents. ${ }^{74}$

Having said that, it is inevitable that there is a gap in the circle-of-trust between public ministries and local contractors, corruption has not faded and risks have become enlarged. ${ }^{75}$ Moreover, although this departure from trustworthy relationships have been recognised by the MoF, the implementation of effective legislations implementing modern practices to invest more in the private sector as framework agreements and private financed projects ('PFI/PPP') is still at a very early stage. ${ }^{76}$

After the flood crises in Jeddah in 2009 and $2011,{ }^{77}$ the need to have lawyers on board became apparent. In response to the crisis, projects were typically delegated by a Royal or Ministerial Order $^{78}$ either to delegate projects to be managed by semi-private organizations, such as Saudi Aramco for King Abdullah University for Science and Technology (KAUST), King Abdullah Petrochemical and Science Research Center (KAPSARC), and King Abdullah Sports City (KASC), or were fully let to foreign companies to undertake the job by Engineering-Procurement-Construction (EPC) agreements, such as railway projects. In order to attract world-class contractors, this approach has required the government to depart from the standard public procurement law (competitive bidding) and move towards direct negotiations with contractors applying a stricter contractor's prequalification mechanism. ${ }^{79}$

The construction lawyer effort in public procurement will be tangent to recognising the total-risk apportionment and competitive-pricing risk with sensitivity among other factors to achieve project success. However, if the project is awarded to a semi-public agency, usually greater room for negotiations and technical qualification will take place.

\subsection{Project Financing}

Construction law also attracts lawyers involved in project and asset-based financial services. The key connection is the project itself. Although many projects today involve lawyers who specialise only in project financing and banking laws, investors look at the package that the project serves, which is reflected in the integration between project documents. The interconnection between finance lawyers and construction lawyers are vital to assure clients with a higher degree of security of what they are paying for. Project financing is an art, which requires the lawyer to pull together the financial capability by the structuring of a framework that studies project tangible and non-tangible assets, designs the procurement routes together with the legal framework of the project, and to be able to secure the best debit-to-equity ratios; if demanded by clients. ${ }^{80}$

In projects, one of the most important channels is the relationship between the financer and the project sponsors. In dealing with this relationship, the construction lawyer's ability to add value will be best endorsed by his competency to have a background of banking and financial laws. Though, it is not a legal restriction to use Islamic finance, and conventional finance is not totally vanished. However, the preference for clients in the region drove its maturity and high demand. The Islamic financial system, ${ }^{81}$ at a high-level doesn't just look at creating profit, but also aims at developing the wellbeing of the whole society. This aim has lessened the appetite of conventional financers in the local Saudi market. Typically, the norm for projects in the Kingdom is to be either publicly or equity-funded. Yet, they are project financing schemes which are commonly available for projects seeking alternative financial modes i.e. debit finance. They are basic modes available in Sharia'a and commonly known in Saudi Arabia that will constitute as an option for alternative financial instruments, ${ }^{82}$ such

\footnotetext{
73 WAS 2013, supra note 71

74 ABA ALKHAIL 2013, supra note 70

75 ALFERAYAN, K. (2012). Changes in Procurement Law Doesn't Abandon Corruption, Al Riyadh Newspaper, July 11, 2012, No. 16088.

${ }^{76}$ BRUCE, B. and WILSON, D. (2000). The Private Finance Initiative, public procurement and the construction industry, I.C.L. Rev., 17(4), 569-592

77 ALSULAMI, M. (2011). Verdicts on Jeddah Flood Crises, Arab News, 400141

${ }^{78}$ ALOMAIR, W. (2012). Prince of Makkah recommends Saudi Aramco Culture in Project Management, Al Riyadh Newspaper, July 2012, No. 16095

79 ALFERAYAN 2012, supra note 74

${ }^{80}$ CAIRNDUFF, M. and COOKLIN, A. (2006). Project financing: different approaches, differing success, W.S.L.R. 2006, 4(10), 12-13

${ }^{81}$ RAY, N.D. (1997). The medieval Islamic system of credit and banking: legal and historical considerations, A.L.Q. 1997, 12(1), 43-90

${ }^{82}$ ARCHER, M. and ABDELKARIM, A. (2002). Introduction to Islamic Finance, Archer and Abdel Karim (eds): Islamic Finance, Innovation and Growth, London: Euromoney, p.3; see also BAKAR, M.D. (2002). The Sharia'a supervisory board and issues of Shari'a
} 
methods typically are:

a) 'Murabha' is a normal sale of goods with an agreed profit mark-up. The financing mechanism takes place when a bank purchases goods upon request from a client. The bank then sells the goods with an added mark-up to the second sale price, after which the client pays the bank back through deferred instalments. ${ }^{83}$

b) Istisna' $a$ where a bank acts as a direct financer for construction work on a current instalment basis, where the principal will then be obliged by Istisna' $a$ terms to pay the bank deferred instalments. ${ }^{84}$

c) Mudaraba is as simple as a project sharing partnership, where the bank acts as the capital provider, and the developer acts as the manager. The amount that exceeds the capital provided by the bank is the shared-profit. ${ }^{85}$

d) Ijarah is an analogues mode of lease agreements. It is usually combined with Istisna'a to form the operational and deferred instalments mode. ${ }^{86}$

e) Musharakah is another level of partnership in which both parties act as managers. ${ }^{87}$

Likewise, recently, the activation of Sukuks - Islamic equivalent of bonds - has become paramount. It almost exceeded 15 Billion US Dollars by the end of year 2012. Later in 2013, that number descended. ${ }^{88}$ The use of Sukuks in project financing is an option for finance modes where the value of tangible assets does not qualify to the level of collaterals required by bankers. It is normally used for mega projects avoiding higher dependability on physical collaterals or tangible assets.

In July of 2012, the MoF enacted a new mortgage law in Saudi Arabia, ${ }^{89}$ which promoted a new pattern that highlights a clearer collateral mechanism. The scheme developed to enable the mid-income community to be able to afford a house through mortgage scheme. Later in 2014, a new condition was added to the same scheme that $30 \%$ of the value of the house has to be paid by the house owner before finance. The decision was recently taken, but the reflection of the media till date is not positive. ${ }^{90}$

At all circumstances, the lawyer main effort in deciding the alternative financing scheme has to address the options available; perhaps those addressed above, and decide the best mode of finance to his client.

\subsection{Insurance and Risk Issues}

The construction lawyer in Saudi Arabia may come across decisions that need an understanding of insurance schemes in the country. The Saudi Arabian Monetary Agency 'SAMA' is the main body regulating and supervising insurance law in Saudi Arabia. ${ }^{91}$ The lawyer practicing in Saudi Arabia must identify, analyse, and address risks associated with construction projects where he can advise clients to take out various policies against such risks. The best practice is to draft a risk register, ${ }^{92}$ in which the project team will identify risks that may arise during the project. When such risks are identified the lawyer may start identifying potential compulsory and non-compulsory insurance policies. ${ }^{93}$

rulings and their harmonization in Islamic banking and finance, Archer and Abdel Karim (eds): Islamic Finance, Innovation and Growth, London: Euromoney, p.76; see also FADEEL, A. (2002). Legal aspects of Islamic finance, Archer and Abdel Karim (eds): Islamic Finance, Innovation and Growth, London: Euromoney, p. 98-99; see also ABDJABBAR 2009, supra note 21.

${ }^{83}$ FADEEL 2002, supra note 81

${ }^{84}$ McMILLEN, M. (2008). Infrastructure Finance: Trends and Techniques, ed. Henry A Davis, Euro Money Inst. Invest., p-386.

${ }^{85}$ McMILLEN 2008, supra note 83, p-388.

${ }^{86}$ AYUB, M. (2007). Understanding Islamic Finance, John Willey \& Sons, p-537

${ }^{87}$ USMANI, M.T. (1998). An Introduction to Islamic Finance, Arab Islamic, Law Series, p-28

${ }^{88}$ Shour'a Council Order 36/51 and 40/39, 1432H; For Sukuk Fakkar J. (2012). 15 Billion USD The Volume of Sukuk by the end of 2012, Al-Eqtesadyiah Newspaper, 6957

${ }^{89}$ Shour'a Council Order 36/51 and 40/39, 1432H.

${ }^{90}$ ALRUWAILI, A. (2014). Having a condition precedent set at $30 \%$ of house value will cancel $90 \%$ of mortgage requests, AlRiyadh Newspaper, 16923

91 Article 2, Royal Decree M/10 dated 1/5/1420 H and Royal Decree M/5 dated 17/5/1405 H

92 PATTERSON, F. D., \& NEAILEY, K. (2002). A risk register database system to aid the management of project risk, International Journal of Project Management, 20(5), 365-374

${ }^{93}$ ZAID, A. A. (2012). An empirical analysis of risk perception, remedial measures and behaviour of people in Saudi Arabia towards insurance, African Journal of Business Management, 6 (10), 3733-3744 
Saudi based insurance companies still did not provide much of options for construction contractors. ${ }^{94}$ Nor, the government tend to enforce insurance requirements on those contractors. ${ }^{95}$ It is understood to be project-related decision rather than a governmental regulatory framework regime. Therefore, the options are limited compared when examining products available, for example, in the United Arab of Emirates construction industry. ${ }^{96}$ The types of insurance policies commonly seen in the construction industry in Saudi Arabia are: All risk insurance, machinery insurance, and in rare circumstances third parties' insurance. Yet, inter alia, professional indemnity insurance, worker's compensation insurance, decennial liability insurance, and delay in start-up insurance are not generally used. The prime reason for those types of policies are not found in Saudi is the technical and legal regulatory environment it needs before enforcement or merely application.

One should know that Islamic Insurance Law is a controversial academic area between legal professionals, Shaira'a scholars, and insurance specialists. ${ }^{97}$ In essence, distinctively, Sharia'a has its own unique law of risk allocations and insurance policy schemes. Mainly, Takaful is the system of governance that encapsulates Islamic-complaint insurance policies. ${ }^{98}$ It is famously known to be the Sharia'a insurance alternative in banking, construction, and other sectors. The Takaful system can produce products that cover those policies aforementioned above and other policies that maybe used as lien insurance or sureties ${ }^{99}$ for national or even international construction projects. ${ }^{100}$ The key difference between a conventional insurance regime and a Takaful system is that the Takaful-based insurance agreements must be strictly an endowment agreement that has a cap of coverage equivalent to the capital owned by the endowed fund. ${ }^{101}$ A Takaful insurance company acts as a trustee by a Wakalah -agency- agreement on behalf of the client. ${ }^{102}$ It could be even extended to cover a Mudarabah agreement which is sort of an investment scheme on the capital of the endowed fund. ${ }^{103}$ Today, almost $63 \%$ of all insurance schemes are covered under this scheme. ${ }^{104}$ On the other hand, because other conventional insurance agreements lacks certainty to expected level of accidents and/or level of coverage, it highly conflicts with the doctrine of Ghrar-induced uncertainty - in Islam. ${ }^{105}$ Therefore, insurance policies taken out in Saudi may have a higher risk of enforcement compared to other jurisdictions. Although, any disputes arisen out of an insurance issue may be heard before a dispute committee in SAMA who has a technical and legal capacity governing insurance schemes. Therefore, it is imperative for the construction lawyer to understand the Takaful alternatives and the limited regulations in the country.

\section{Construction Practice Areas}

\subsection{Costing, Loss and Expense Issues}

Great portions of claims admitted to courts in Saudi Arabia are with reference to a costing or loss and expense issues. It is also known to be of a relative nature in other jurisdictions. They are indeed among the major types of claims famously known in construction projects. Inevitably, the resolution of such claims requires a thorough understanding of areas such as: quantity surveying, construction plans, financial engineering, and law applicable to contracts. Usually, a professional -quantity surveyor - or a team that is capable of breaking down the project into manageable parts to determine the scope of work is required to ascertain a claim of loss and expense and valuate it.

As discussed earlier the general norm of projects in Saudi Arabia is to be awarded on competitive bidding basis.

\footnotetext{
94 ZAID 2012, supra note 92; see also LEVINE, M., ROGER, T., Q. C. (2013). Construction insurance and UK construction contracts. CRC Press; see also KNOCKE, J. (Ed.). (2003) Post-construction liability and insurance. Routledge

${ }_{95}$ ZAID 2012, supra note 92; see also MANKABADY, S. (1989). Insurance and Islamic law: The Islamic insurance company, Arab Law Quarterly, 199-205.

${ }^{96}$ Lloyd, E. (2014). Insurance in Construction Contracts: A Few Things to Know, Al Tamimi \& Co Newsletter

${ }^{97}$ KHORSHID, A. (2004). Islamic insurance: a modern approach to Islamic banking. Routledge; see also ZAID 2012, supra note 92

${ }_{98}$ MAYSAMI, R. C., WILLIAMS, J. J. (2006). Evidence on the relationship between Takaful insurance and fundamental perception of Islamic principles, Applied Financial Economics Letters, 2(4), 229-232

99 BRENDEL, N., BARRETEE, A. and EL-RIACHI, W. (2010). The availability in the UAE of liens to secure payment under construction contracts, A.L.Q. 2010, 24(3), 309-317

${ }^{100}$ GOSDIN, J. (2007). Title insurance: a comprehensive overview, American Bar Association. Section of Real Property, Probate, and Trust Law; Mutual Co-operation, REST, J. (2005). First Lloyd's syndicate offers Takaful as Islamic insurance demand soars, L.L.I.D., Dec 2, 3.

101 AYUB 2007, supra note 85, p-537

102 AYUB 2007, supra note 85, p-537

${ }_{103}$ AYUB 2007, supra note 85, p-267

104 JAFFER, S. (2007). Islamic Insurance: Trends, Opportunities and the Future of Takaful, EuroMoney Books, p-XV

${ }^{105}$ AYUB 2007, supra note 85, p-537
} 
The contractor who has been awarded the project will normally be one of lowest bidders. That lowest bidder if he factors-in all the risks associated with every manageable part; his bid has a tendency to fail. Therefore, construction projects tend to inherit being a sensitive business. The main reason is the fact that those projects are being under the line of irregular loading of contingency factors between all project components. Yet, higher value projects that also may still have a potential ambiguous scope will tend to have a payment mechanism on measurement basis. As a result, most of claims falling under the category of Costing, Loss and Expense are either brought on the grounds of contingency-free pricing, measurement process, ascertainment, and final valuations. The same reasoning is extended to include fixed-price agreements. The important character is to know that the Saudi position in this category is with no much difference from other jurisdictions. In Saudi Arabia, courts will appoint normally professional engineering offices or sometimes accounting firms to ascertain and valuate such claims.

Currently, in ascertaining loss and expense claims before any tribunal in Saudi Arabia, it is presumed that the manageable quantifiable loss has to be assumed, quantified, and linked to the cause of the loss. In Shaira'a, the general principle is that a party may receive damages equivalent to the loss incurred and caused by the other party. ${ }^{106}$ However, the lawyer must still prove that a claimant actually suffered a loss that is not too remote and that the loss was caused by a breach of the defendant. ${ }^{107}$ Also, consequential losses and profits can be recovered if they were directly charged. ${ }^{108}$ Although, there is no case laws to support such argument, the practice today is left to the sole discretion of the tribunal.

Together with other experts, the lawyer in Saudi Arabia must pull together material facts necessary to formulate a cause-of-action and advance it to the acting tribunal. This cause-of-action will require all material evidence to prove the allegations ascertained in his pleadings to form a certain type of a claim. Although not impossible, it is still not examined how a tribunal will decide a claim of the grounds of loss and expense. In deed, a practicing lawyer may still expect the local courts use what is known as: ${ }^{109}$ a) global claim; b) a total cost claim; or a c) modified total cost claim. ${ }^{110}$ Yet, the enforcement of technical report advancing any of the previous methods, it will still highly persuade the judge decision.

Unfortunately, there is no reference to say what is the procedure adopted by the Saudi courts. Yet, as said above, it is a general practice a judge will appoint an expert to valuate a claim, either an accounting firm, an engineering firm, or directly valuated by the Saudi Council of Engineers. The method of calculations and ascertainment will be under the discretion of any of the former parties. The lawyer, then, following the aforementioned risks, and their associated durations, has to incubate those factors for any claim admitted to a local court to decide a loss and expense issue.

\subsection{Time Claims and Schedule Issues}

After developing the planning documents, each construction project runs on a specific schedule, usually approved by the employer, where they base the measurement of successful timely-completion on start dates, end dates, durations, delays, and substantial and final completion dates. The construction lawyer's role in this regard is mainly to advise his clients on the legal effect or the grounds of any contractual obligations enforcing certain time-constraints, delay events, damages, and procedures wherever his position is on the project. Yet, as delay in construction is almost inevitable in every project, ${ }^{111}$ it is a norm to have time issues arising out in disputes heard before any tribunal in Saudi Arabia.

The private sector still does not have standard forms of agreements, therefore, application of a plenty will be dependant on negotiations and bespoke agreements. For those contracts governed by the Saudi public procurement law, the practice is to apply a formula calculating delays and penalizing those contractors who fail

\footnotetext{
106 ALSAMMARI, K. (2010). Reimbursement of Incurred Losses Between Sharia'a and Law, AlJazirah Newspaper, Issue 13791, $02 / 07 / 2010$

107 ALSAMMARI 2010, supra note 105; see also in the United Kingdom, Saunders ESQ., J.S., (1831). The Law of Pleading and Evidence in Civil Actions, V-1, Robert II Small

${ }^{108}$ Based on case reports admitted to Saudi Tribunals by a local Engineering firm in a case under the administration of the Chamber of Commerce in Dammam

109 In the United Kingdom, applying John Holland Construction \& Engineering Pty Ltd v Kvaerner RJ Brown Pty Ltd 82 B.L.R. 81, also John Doyle Construction Ltd v Laing Management (Scotland) Ltd [2004] S.C.L.R. 872

${ }^{110}$ DAVIDSON, R. P. and MULLEN, J. (2009). Evaluating Construction Claims, $2^{\text {nd }}$ Ed, Willey-Blackwell, p-78; LAL, H. (2002). Quantifying and Managing Construction Claims, Thomas Telford Pub., $1^{\text {st }}$ Ed, p-208

111 AL-KHARASHI and SKITMORE 2009, supra note 7
} 
to deliver on time. ${ }^{112}$ However, for those contractors coming from other parts of the world, they are used to having such clauses being unenforceable. ${ }^{113}$ In banking, it has been clear that any penalty applied by banks to credit cards is non-Sharia'a complaint. ${ }^{114}$ However, ironically, there are Fatwas from scholars to legalize a penalty only on construction contracts based on 'necessity and commercial need'. ${ }^{115}$ Yet, as it is unclear by Saudi law who has the right to penalize, where, reciprocally, will eventually receive an advantage. ${ }^{116}$

In common law jurisdictions, legitimacy of time-related claims is established by the principle that time is of the essence and failure to complete on time may entitle the employer to receive damages. ${ }^{117}$ Rather in Saudi, more recently, another legal viewpoint is accounting the penalty to be calculated as a discount which a contractor offers from the total sum of the contract price for each delay for which he is responsible. ${ }^{118}$ Although, this late viewpoint may account to be legitimate ground for its application, the government did not show intention to change.

For cases admitted to tribunals in the Kingdom, the law has not yet examined any of the delay analyses modes. ${ }^{119}$ For those lawyers expecting to have a tribunal where it is required to present a delay analysis, they still can use the following time claim evaluation procedures as: as-planned vs. as-built; impact as-planned analysis; collapsed as-built analysis; time impact analysis; and/or productivity analysis. ${ }^{120}$ To date, the general assumption that the same enforcement application of loss and expense claims prevails for time-associated claims too.

\subsection{Quality and Defect Issues}

Forming the triangle of project pillars, the next area of construction claims concerns with construction defects and quality deficiencies. The success of delivering any rate of a desired-quality lies in the documentation system during the construction period. When developing quality metrics, the construction lawyer can assist in providing the legal support of quality-related issues. For example, the lawyer is able to assess whether the test of the final product should be examined through reasonable skill and care or is to fit for its purpose. ${ }^{121}$ Another example, to verify the results of a concrete slump test, an examiner needs to have documents showing, inter alia, the specifications required, the manufacturing of the mix, lab tests, on-site test, the contractor's daily reports, and the engineer's daily reports. ${ }^{122}$ The legal foundation encompassing such technical process can be apportioned to the lawyer.

In addition, a major area of disputes in a construction project is the defect liability period, which is another area in which a construction lawyer will be a core player. Because the lawyer understands the consequences and the effect of decisions undertaken by the project team, he will generally be a prime decision maker regarding the date of substantial completion, ${ }^{123}$ the defect liability period, ${ }^{124}$ and the final hand-over of a project. ${ }^{125}$ In Saudi

\footnotetext{
112 Royal Decree 58/M, 9/4/1427 H

113 PICVANCE, K. (2004). Delay and Disruption in Construction Contracts, T\&F Informa; see also the verdict in Dunlop Pneumatic Tyre $v$ New Garage \& Motor [1915] AC 79.

${ }^{114}$ MAALI, B., CASSON, P., \& NAPIER, C. (2006). Social reporting by Islamic banks, Abacus, 42(2), 266-289; see also VAN SCHAIK, D. (2001). Islamic banking, The Arab Bank Review, 3(1), 45-52

115 SENIOR FATWA COMMITTEE (1994). Senior Fatwa Committee Series, 1/214, Fegh Council in Saudi Arabia

116 AL-KHARASHI and SKITMORE 2009, supra note 7

117 see in the UK the case of Dunlop Pneumatic Tyre Co Ltd v Selfridge \& Co Ltd [1915] UKHL 1, [1915] AC 847

118 ALMUNAJID, M (2010). Fatwa on Penalty Charges, Islam Question and Answer, http://islamqa.info/en/105290

119 Author's own experience in searching through cases admitted to courts in Dammam, Riyadh, and Jeddah.

120 ARDitiL, D. and PATTANAKITCHAMrOON, T. (2008). Analysis Methods in Time-Based Claims, Journal of Construction Engineering and Management, Vol. 134, No. 4; see the analysis in Henry Boot Construction v Malmaison Hotel [2001] Q.B. 38.

${ }^{121}$ See the examination of the effect in Independent Broadcasting Authority $v$ EMI Electronics Ltd (1978) 11 BLR 29

${ }^{122}$ For reference on typical construction technical work see CHUDLEY, R., GREENO, R. (2008). Construction Handbook, $7^{\text {th }}$ Ed, Elsevier

${ }^{123}$ THOMAS, H.R., SMITH, G.R., and CUMMINGS, D.J. (1995). Have I Reached Substantial Completion, Journal of Construction Engineering and Management, Vol 121, No-1; see also TOTTENHAM, M. (2004). Summary judgment - RIAI standard form building contract - interim certificate - Defects Liability Period - whether interim certificate could be used to adjust payments in respect of defects that became apparent after certificate of practical completion, C.P.L.J. 2004, 9(2), 46-47; see also THOMPSON, T. (2004). Practical completion in building contracts: a legal definition?, Const. L.J. 2004, 20(6), 301-318; LANE, N. (2007). 10 things you need to know about practical completion certificates, Building 2007, 36, 58

${ }^{124}$ CHAN, R. (2002). Update on China's defects liability regime, I.C.L. Rev. 2002, 19(4), 534-539; see also NORTON ROSE (2000). Latent defects, collateral warranties and joint and several liability, Comm. L.J. 2000, 12, 11-12.

${ }_{125}$ TOTTENHAM, M. (2004) Contractual dispute - administrative fees - whether fees contingent on completion of proposed construction project., C.P.L.J. 2004, 9(2), 41-42
} 
Arabia, most public contracts have a warranty period ranging from 6 months to one year. ${ }^{126}$ This period is still not enforced by local regulations. Yet, it is still unclear whether or not a contractor is liable after the lapse of warranty. By the application of principles of Hadd and Qysas theory, ${ }^{127}$ the liability under Sharia'a does not have the same grounds in the ability to bring a claim before any court of Sharia'a. In essence, whether or not a prescription period has elapsed will be decided on the sole discretion of the judge. ${ }^{128}$ In effect, it is under his discretion to decide whether the defect has proportionally out-dated the right to be compensated for. ${ }^{129}$

When a claim is brought to a local court and the issue to be decided is linked to a quality matter, the judge will be appointing a local engineering office to advise on the technical merits of the dispute. Thus, the advice of the local engineering office will not have a binding effect; yet, the technical report will highly persuade a judge decision.

\subsection{Duties and Responsibilities Issues}

The success of any project depends highly on those who execute it. The organizational structure of any project is usually projectized or matrix oriented. ${ }^{130}$ Both structures contain complex lines of communications and responsibilities interfacing each other. The local authorities in Saudi Arabia will approve a planning permission and pass over a construction permit if the project has an employer, an engineering office, and a contractor. Until today, the local authorities do not interfere with construction contracts or the structure of the project as it is left to sole discretion of the employer. An employer has, at his own privilege, the right to extend the structure to include a property manager, sub-contractors, a project manager, and a quantity surveyor. The construction lawyer's expertise, aligned with the project management team, must expand in elaborating the duties and responsibilities of those involved in a project. A practicing lawyer in Saudi Arabia must review the local laws before advising on the duties and responsibilities of his clients. The shape of the organizational structure must be developed after reviewing employment laws, ${ }^{131}$ corporate laws, organizational policies, ${ }^{132}$ and project contracts.

It is central to achieve a successful project structure to have the procurement route designed alongside with the duties and responsibilities of those involved in the project. It is also highly imperative before advising on the structure, to review, perhaps with a corporate lawyer, the type of local companies and corporations. The Saudi corporate law is also distinctive from other parts of the world. A limited liability company is the most common vehicle for equity participation. The parties involved will only be liable to the extent of the debits amounting to their current subscription of shares. Yet, a construction project is expected to have at least one, if not more, professional company that provide engineering, project management, or supervision services. The Saudi laws until today does not enforce Professional Indemnity Insurance (PII) in order to practice as a professional. On the face of it, this may account tougher exposure of risk on professionals more than they can afford. The current status is that those subscribing in a professional company are exposed to debits of the company, whatever is their equity level, or personal capacity level. At the other far end, semi-government employers as Saudi Aramco, have a condition precedent to qualify as a professional company is to provide a PII on cap or aggregate basis. Foreign companies, although, they are seeing more lenient requirements with time for them to be qualified to projects are no exception to investment and corporate local laws.

With that, the lawyer's final step at this stage is to look after collateral warranties and the rights of third parties. ${ }^{133}$ For example, in the drafting stage, a construction lawyer must balance and look for areas of vague

\footnotetext{
${ }^{126}$ Article 76, Public Procurement Law in Saudi Arabia (2009). Government Tender and Procurement Law Official Translation Manuscript, Saudi Laws

127 JARADAT, A. (2012). Theory of Application of Judicial Verdicts in Islamic Jurisprudence - Hadd, Qysas and Tazeer - a comparative study, Dar Al Thagafah wa Al Nashir

${ }^{128}$ For the comparative analyses in Sharia'a to the effect of prescription periods see ALBASRI, H (2000). Prescription between Sahria'a and Law, Al Nabaa Magazine, v.42

129 ALBASRI 2000, supra note 127

${ }^{130}$ GITMAN, L. and McDANEIL, C. (2009). The Future of Business: The Essentials, South-Western CENGAGE Learning; PMI 2009, supra note 11

${ }^{131}$ KIRTZALIS, A. (1994). Regional Developments - Saudi Arabia, 28 Int'l L. 449; ASHERMAN, J. (1982). Doing Business in Saudi Arabia: The Contemporary Application of Islamic Law, 16 Int'l L. 321 (1982).

132 BARBEITO, C. (2004). Human resource policies and procedures for nonprofit organizations, Wiley Pub., p-69; CHENOWETH, M. HUNTER, S., KELTNER, B., and ADAMSON, D. (2004). Organizational policy levers can affect acquisition reform Implementation in Air Force Repair Contracts, RAND Press, p-22

133 BROWN, N. (1999). Let the builder beware? A guide to appointments and collateral warranties on construction projects, C. \& E.L. 1999, 4(5), 20; see also CORNES, D. (1991). Collateral warranties - a practical guide for the construction industry, Const. L.J. 1991, 7(2), 164
} 
exclusion or imposition, such as, (1) employer's warranty liability to the contractor; (2) employer's remedies against the engineer; (3) the engineer's authority; (4) the engineer's responsibility; and (5) and the contractor's warranties. ${ }^{134}$ Therefore, without a lawyer in construction projects, the management of such projects may not be seen as sensible. The requirement to take out warranties is also with a distinct application in Sharia'a. Granting a warranty under Sharia'a requires a proper analysis of the doctrine of Ghrar, ${ }^{135}$ the extent of exclusion or imposition, the nature of the warranty, the position of the warrantor, and the position of the warrantee. ${ }^{136}$ Again, the critical area of law to be examined in here are the principles of Hadd and Qysas theories, ${ }^{137}$ where each situation will be drawn from Hukums already established in Islamic Jurisprudence. ${ }^{138}$

\section{Dispute Resolution}

A key role of the practice of construction law in Saudi Arabia is resolving disputes. Since disputes in the construction industry are inevitable, ${ }^{139}$ a worldwide debate on the construction lawyer's role in either managing or resolving disputes became prominent. ${ }^{140}$ On one hand, the practical awareness that construction disputes cannot stand the burden of litigation is internationally recognized. ${ }^{141}$ On the other, alternative dispute resolutions are showing promising progress in resolving disputes in the construction industry. ${ }^{142}$ Nevertheless, there are those who believe that litigation is inevitable if lawyers are delegated the power to decide disputes. ${ }^{143}$ Thus, disputes pertaining to on-site construction, if impartially decided, tend to lack adequate technical facts and final closure. ${ }^{144}$ Therefore, by an exercise of risk balancing, normally construction disputes were seen to require a lawyer to decide the essential legal merits of any dispute; especially complicated ones. ${ }^{145}$ Yet, in an ideal scenario, by weighing the facts of the construction industry practice, managing disputes will be the prime success of the lawyer's immersion. ${ }^{146}$ The same discussion is extended to the Saudi construction industry. This section of the paper will review the alternative dispute resolution routes available in the Kingdom.

\subsection{Administrative Court and Sharia'a Courts}

The Board of Grievances was established in May 1982 to be the sole tribunal for most commercial and administrative disputes. ${ }^{147}$ Today, since 2012 , an execution judge who has a fast-track requirement to make a verdict on a specific dispute have the sole jurisdiction to enforce foreign judgments and arbitral awards. ${ }^{148}$ Thus, the Board still have jurisdictions mainly are claims brought against governmental bodies. ${ }^{149}$ This change came to effect after flood of international criticism on the Saudi judicial system, which, in the last decade, made the government suffer and encounter major conflicts seeking enforcement of decisions with countries that have no reciprocal recognition of authority. In response, the government has almost spent more than $\$ 2$ billion worth of investments with which to develop the judiciary system as a whole. ${ }^{150}$ As the law of judiciary is the primary reference governing the courts in the Kingdom, ${ }^{151}$ being included in the recent changes, lawyers saw greater

\footnotetext{
${ }^{134}$ LORD, J. (1987). Five Things Every Attorney Should Consider Before Approving Construction Contracts for Owners, Developers, and Lenders, 7 Constr. Law. 5

135 AYUB 2007, supra note 85, p-537.

${ }^{136}$ HANCHER, D. (1993). Use of Warranties in Road Construction, NCHRP Synth 195, Transportation Research Board, National Research Council

137 JARADAT 2000, supra note 126

138 JARADAT 2000, supra note 126

139 AL-KHARASHI and SKITMORE 2009, supra note 7

140 SAMUELS, D. (1998). Preventative lawyering: Mrs. Beeton meets ER, I.C. Lit. 1997/1998, Dec/Jan, 10-12

${ }^{141}$ RYLAND, J. (2010). Review of civil litigation costs, December 2009 - construction litigation and the TCC, Const. L.J. 2010, 26(7), 589-597; REYNOLDS, M. (2000). Construction litigation practice, C. \& E.L. 2001, 6(1), 50-52

${ }^{142}$ REYNOLDS 2000, supra note 140

143 JONES 1994, supra note 1

144 GEISINGER 2009, supra note 22.

145 CAMPBELL, L. (1980). The Role of The Construction Consultant, 1 Constr. Law. 3; see also GROTON, J. and WILDMAN, W. (1992). The Role of Job-Site Dispute Resolution in Improving the Chances of Success of a Construction Project,12 Constr. Law. 1.

146 SAMUELS, D. 1998, supra note 139.

${ }^{147}$ Royal Decree No. 58/M, 17 Rajab 1402H; Royal Decree No. 78/M, 19 Ramdan 1428H

${ }^{148}$ Royal Decree No. 58/M, 17 Rajab 1402H; Royal Decree No. 78/M, 19 Ramdan 1428H

149 Osamah AlJamman, Interview with Shaiek Mohammed AlDossary (2011). Head of the Supreme Court: Awaiting Claim Procedure to Start Delegation Process and Jurisdictions Regulations, 16 May 2011, No. 633045

${ }^{150}$ AL-FADHEL, F. (2009). The new judicial system of Saudi Arabia, Arbitration, 75(1), 91-94

${ }^{151}$ Royal Decree No. 64/M, 7/14/1395 H
} 
latitude facilitating greater transparency and productivity in the system. ${ }^{152}$

Construction-related disputes take up much of the courts' attention. It is estimated that construction related disputes consume approximately $60 \%$ of the time of the local administrative courts. ${ }^{153}$ A great portion of that time is involved in enforcing arbitral awards foreign and local. International qualified lawyers still don't have the right for advocacy in Kingdom. Yet, law firms have not regarded that of being an obstacle as assistance from a local litigator can be acquired. Nowadays, most law firms registered in Saudi have had experiences with the Saudi courts. Having said that, some believed that the system might have contributed to make Litigation to be the most burdensome route for those seeking fast closures. ${ }^{154}$ A lawyer before making a decision to go for litigation has to equip himself with areas of procedural and jurisdictional issues in Saudi.

\subsection{Ministerial and Governmental Committees}

It has been a trend in Saudi Arabia to have cases reviewed by specialised committees. The Ministry of Labour (MoL) has its own internal committees located in every labour bureau around the Kingdom. A higher order commission located in Riyadh is directly linked to the Undersecretary of the MoL Affairs. The jurisdiction of the commission entails rendering final judgments on all claims and imposing penalties against employment law violators. ${ }^{155}$ Workplace safety and construction site employment relations are admitted to the Labour Committee. ${ }^{156}$ The Ministry of Commerce $(\mathrm{MoC})$ also has a specialised committee to look over commercial frauds and commercial disputes. ${ }^{157}$ The law of procedure before courts enacts the primary action behind admitting a case to a specialised tribunal including MoL and MoC committees. ${ }^{158}$ Those committees too have been under development in the past three years. ${ }^{159}$ The lawyer has to know other committees also available in other ministries and governmental bodies.

Another alternative seen available today, mainly preferred by international companies is to bring international disputes before the Chamber of Commerce. The aim is to have higher degree of caliber where the dispute requires experienced technical, commercial, and legal knowledge. ${ }^{160}$ The Amarah, acting as an ombudsman, mainly has a jurisdiction over criminal cases, and it is usually an enforcement wing. ${ }^{161}$ However, cases could be referred to the Amarah to seek immediate specific performance, though in rare instances only.

\subsection{Arbitration}

Those looking for an alternative binding decision may see the practice of arbitration, ${ }^{162}$ today famously known in Saudi Arabia, ${ }^{163}$ to be more influential. Although, the ability to decide a dispute by arbitration rules may provide greater latitude to decide variety of disputes in Saudi Arabia, ${ }^{164}$ a clear difficulty of enforcement is evident. ${ }^{165}$ Provided that the parties have chosen their own arbitrator, a judge may influence the decision dramatically to conform it within Sharia'a contemplations. A common example is the rejection of any clause applying 'interest' - Riba - mechanism, which is forbidden in Islam.

On April 16, 2012, a new arbitration regime was published. ${ }^{166}$ In fact, up to the date of publication of this paper it did not come into force. ${ }^{167}$ The new regime has been applauded in the local and international media, ${ }^{168}$

152152 AL-FADHEL, F. 2009, supra note 149.

153 ALRABYEAH, A. (2007). Construction Cases in Court Houses, Al-Al Sharaq Al Awsat News Paper, 10534

154 RYLAND 2010, supra note 140; REYNOLDS 2000, supra note 98; AL-AMMARI, S. (2010). Saudi Arabia and the Onassis arbitration - a commentary, J.W.E.L. \& B. 2010, 3(3); 257-259; AL-SAMAAN, Y. (1994). The settlement of foreign investment disputes by means of domestic arbitration in Saudi Arabia, A.L.Q. 1994, 9(3), 217-237

155 Royal Decree No. M/51, 23 Sha'ban 1426 / 27 September 2005.

${ }^{156}$ Royal Decree No. M/51, 23 Sha'ban 1426 / 27 September 2005.

${ }_{157}$ Ministerial Decree No. 66, enacted 4/6/1374 H, Royal Decree No. 45, 14/8/1381 H and amended by Royal Decree 19/M 4/23/1429 H.

${ }^{158}$ Royal Decree No. 21/M, 20 JumadaI 1421

159 ALJAMMAN 2011, supra note 148

${ }^{160}$ Royal Decree No. 21/M, 20 JumadaI 1421

${ }^{161}$ FRIDE \& CARNEIGE Report in Saudi Arabia (2006). Arab Political Systems: Baseline Information and Reforms - Saudi Arabia, FRIDE and Carnegie Endowment for International Peace.

162 TACKABERRY, J. (2009). Adjudication and arbitration: the when and why in construction disputes, Arbitration, 2009, 75(2), 235-243

163 AL-AMMARI 2010, supra note 153; see also AL-SAMMAN, Y. (1994). The settlement of foreign investment disputes by means of domestic arbitration in Saudi Arabia, A.L.Q. 1994, 9(3), 217-237

164 RAWACH, E. and EL-RAYES, R. (2006). The law of arbitration in Saudi Arabia: reality and perceptions, I.B.L.J. 2006, 5, 617-631

165 AL-AMMARI 2010, supra note 153.

${ }^{166}$ Royal Decree 46/M, 7/12/1403 H

167 AL-AMMARI, S. (2014). New Arbitration Law Specific Change (1 of 2), Al Yaum Newspaper, Jan 13, 2014, No. 3115352 
especially for businesses seeking greater confidence in local dispute resolution. ${ }^{169}$ It is believed that a centre to hear disputes placed in Riyadh will accompany its enforcement. ${ }^{170}$ The main conflict with the previous arbitration regime was its connection and conformance with international arbitration. The 1983 regime ${ }^{171}$ had difficulty in referring governmental disputes to arbitration, ${ }^{172}$ each arbitrator had to be a Muslim male, ${ }^{173}$ and arbitral awards had to be issued within 90 days of the commencement of arbitration proceedings ${ }^{174}$ extension provisions were readily available. ${ }^{175}$ At all circumstances, in kingdom, enforcement had to be ratified by a Sharia'a court. ${ }^{176}$

The new regime ${ }^{177}$ replaced the old and has major advantages. The first is that, even if a contract has been terminated or has become ineffective, an agreement to proceed to arbitration is still valid, ${ }^{178}$ provided that arbitration is explicitly mentioned or incorporated by reference. ${ }^{179}$ Sharia'a degree holders ${ }^{180}$ remain dominating when the new regime enforces any sole arbitrator or chairman of the panel be a holder of a Sharia'a or a legal degree with Islamic background. ${ }^{181}$ Yet, parties may choose the arbitrator or at least nominate one of three especially when they are obliged to declare any potential conflict of interest.

In addition, the tribunal has the power to compel any authority or expert witness to testify or any third party to produce documents. ${ }^{182}$ Also, when parties do not choose arbitration rules, a default mechanism applies within the new regime. ${ }^{183}$ Arbitrations are conducted in the Arabic language even if the parties chose other languages. ${ }^{184}$ In every tribunal, the arbitrator is obliged to apply substantive law even if it is not the law of Saudi Arabia. ${ }^{185}$ The time limit imposed to issue an award is 12 months. ${ }^{186}$ A major advantage is the inability of the court to revisit the merits of the case or the facts of the dispute. ${ }^{187}$ Only applications containing jurisdictional challenges and questions invalidating a Sharia'a principle or a question of law can be referred to courts. ${ }^{188}$

\subsection{Saudi Engineering Council}

The Saudi Engineering Council (SEC) ${ }^{189}$ has a dedicated division to promote arbitration for construction and engineering claims. ${ }^{190}$ An application to arbitration will be submitted either to the SEC or to an Administrative Court. If the SEC is tribunal before the claim, parties of the dispute do not have the ability to name, choose, or communicate with arbitrators. ${ }^{191}$ Communication is limited to a judge of an Administrative Court or an SEC representative. ${ }^{192}$

\footnotetext{
${ }^{168}$ ALJARBA, M. (2012). The New Arbitration Law Can Hear Disputes Without The Need for a Chamber, Al Jazeerah Newspaper, June $8^{\text {th }}$, 2012, No 20120608

169 AL-AMMARI 2014, supra note 166

170 ALJARBA 2012, supra note 167

171 ALJARBA 2012, supra note 167

172 ALJARBA 2012, supra note 167

173 ALJARBA 2012, supra note 167

174 ALJARBA 2012, supra note 167

175 ALJARBA 2012, supra note 167

${ }^{176}$ Royal Decree 46/M, 7/12/1403 H

177 ALJARBA 2012, supra note 167

${ }^{178}$ Royal Decree 34/M, 5/24/1433H.

179 ALJARBA 2012, supra note 167

180 ALJARBA 2012, supra note 167

181 Royal Decree 34/M, 5/24/1433H.

${ }_{182}$ Royal Decree 34/M, 5/24/1433H.

183 ALJARBA 2012, supra note 167

${ }^{184}$ ALJARBA 2012, supra note 167

${ }^{185}$ Royal Decree 34/M, 5/24/1433H.

186 ALJARBA 2012, supra note 167

${ }^{187}$ Royal Decree 34/M, 5/24/1433H.

${ }^{188}$ Royal Decree 34/M, 5/24/1433H.

189 ALJARBA 2012, supra note 167

190 ALJARBA 2012, supra note 167

${ }^{191}$ Saudi Engineering Council, Board Directive 3/13/3/31, in mid 1413H.

192 ALJARBA 2012, supra note 167
} 


\subsection{Alternative Dispute Resolution}

Alternatively, those who are looking for a more cost-effective mechanism seek the practice of Alternative Dispute Resolution (ADR), ${ }^{193}$ which understands the nature of confidentiality, is time-effective, and involves less effort. ${ }^{194}$ The Saudi construction lawyer role will be one of the best to serve the decision maker ${ }^{195}$ in ADR. He can also be as a counsel in an ADR session representing a client. However, provided he was appointed as a counsel, he has to make sure how to tackle mediation sessions, as there is no law in Saudi Arabia protecting clients or enforcing pre-court mediation. In case a lawyer has been appointed at the early stages of the project, clients may take the advantage him being able to produce suite of documents translated into legal pleas that can be easily read in an ADR tribunal. ${ }^{196}$

\section{Corruptions and Project Forensics}

An area that is not regularly seen in the practice of construction law in Saudi Arabia is; project forensics. Having a person who understands the law and who has the ability to build a suite of documents to trace forensically fraud in construction projects is still at its early stages in Saudi Arabia.

A practicing construction lawyer dedicated to construction and project forensics understands the technical forensic knowledge and investigations experience required. ${ }^{197}$ Another practice that a Saudi construction lawyer must come across is the local and international regimes of competition law. ${ }^{198}$ It is to understand the ability to determine fraud practices in construction commercial deals and tendering processes, such as, inter alia, bid rigging, cartels, price fixing tenders, and mergers. ${ }^{199}$ The newly established National Anti-Corruption Commission $^{200}$ 'Nazaha'; is devoted to be the dedicated public body concerned with this area of practice. Though Nazaha has been facing difficulties created by the local media in relation to its jurisdiction ${ }^{201}$ especially in construction-related fraud cases, ${ }^{202}$ it is believed that the Kingdom is still at the early stages of a construction-related corruption and fraud system. ${ }^{203}$

\section{Conclusion}

The uniqueness of this paper lies in its nature. It is mainly exploratory to assist future research in the area of projects and construction law in Saudi Arabia. It is not to provide solutions, keeping the chance for further research to explore more attributable solutions to each practice area. The difficulty in finding references may have contributed to having the discussion more generalized in some areas of practice. In spite of having the discussion wide to include most of the subjects found in Universities' syllabus, the review should enable construction lawyers have a background on what is current status que.

From the review above, it was clear that Saudi construction law practice is a broad area of knowledge. To encapsulate the practice, the discussion of the paper took headings of courses teaching the subject in international universities and practitioners' books. Despite the shortcomings in the practice, the market review showed higher value of involvement of lawyers in the construction industry. Some researchers thought a single lawyer for the project would suffice even.

\footnotetext{
${ }^{193}$ WOOD, T. and SMITH, C. (2005). ADR in construction disputes, Cons. Law 2005, 16(7), 23-25

${ }^{194}$ COHEN, M. and GOULD, N. (1998). ADR: appropriate dispute resolution in the UK construction industry, C.J.Q. 1998, 17(Apr), 103-127; WOOD, T. and SMITH, C. 2005, supra note 192

195 WHITTAKER 2003, supra note 26; GEISINGER 2009, supra note 7.

196 BROOKER, P. and LAVERS, A. (2005). Construction lawyers' experience with mediation post-CPR, Const. L.J. 2005, 21(1), 19-46; see also BROOKER, P. (2002). Construction lawyers' attitudes and experience with ADR, Const. L.J. 2002, 18(2), 97-116; see also BENNETT, S. (2005). Discovery in construction litigation: the challenge in protecting privilege, Const. L.J. 2005, 21(5), 361-368

${ }^{197}$ KAMINETZKY, D. (2001). Design and Construction Failures Lessons From Forensic Investigations, Galgotia Publications; see also CAMPOBASSO, C. P., FALAMINGO, R., \& VINCI, F. (2003). Investigation of Italy's deadliest building collapse: forensic aspects of a mass disaster, Journal of forensic sciences, 48(3), 635-639. see also ATKINSON, A. (1998). Human error in the management of building projects, Construction Management \& Economics, 16(3), 339-349.

${ }^{198}$ LEVERETT, F., \& BADER, J. (2005). Managing China - US energy competition in the Middle East, The Washington Quarterly, 29(1), 187-201; see also MESSERLIN, P. A. (1990). Anti - Dumping Regulations or Pro -Cartel Law? The EC Chemical Cases, The World Economy, 13(4), 465-492; see also KEMPTON, J., HOLMES, P., \& STEVENSON, C. (1999). Globalisation of Anti-Dumping and the EU, Sussex European Institute.

199 BROADER, D. (2010). USA: anti-competitive agreements - bid rigging, E.C.L.R. 2010, 31(3), N36a

${ }^{200}$ Royal Decree 65/A, 4/13/1432H.

201 ALSHAREEF, R (2014). Nazaha: The Right Way Should be Followed, Sabq Online Newspaper, May $3^{\text {rd }}, 2014$

${ }^{202}$ ALANSARI, A. (2014). Nazaha: The Execution of Governmental Projects are at Top Metrics for Nazaha, Al Eqtasdiyah Newspaper, September $3^{\text {rd }}, 2014$, No. 7638

${ }^{203}$ ALSHAREEF 2014, supra note 198
} 
The general view is that the Saudi construction industry will tend to have much difficulty compared to other jurisdictions. The biggest hurdle is found in the irregularity of application of jurisprudence and law. Insufficient regulations to standardize bespoke standard forms or suite of standard projects and construction documents increased the difficulty. Yet, the practice of procurement, project finance, and insurance schemes are at a higher maturity level. It may be attributed to better banking systems and tougher Capital Markets regulations. From the review, the paper showed that Judges normally would deprive themselves to decide construction common issues matters as time, cost, and quality. They will tend to have a non-binding but persuasive support from a local professional body. The paper also presented the recent optimistic developments in the judicial system, supported by local views on the progress and future of further developments. Furthermore, the paper has showed generally the effect of choosing any of the dispute resolution routes available.

Eventually, the paper showed greater area of future research and advancing developments in the practice. It also showed a greater latitude inherently built in the practice for the construction industry practitioners to decide their own preferred choices when it comes to bespoke standard forms of contracts, suites of project documentations, procurement routes, finance, insurance, and dispute resolution forms.

\section{Acknowledgments}

I would like to pass my special thanks to Brodie McAdams, Unviersity of Salford and Dr. Francine Baker, Wolfson College, Oxford University for reviewing and commenting this work. I also would like to pass my thanks to my father Dr. Khaled Medallah for his continuous support.

\section{Copyrights}

Copyright for this article is retained by the author(s), with first publication rights granted to the journal.

This is an open-access article distributed under the terms and conditions of the Creative Commons Attribution license (http://creativecommons.org/licenses/by/3.0/). 